\title{
THE HISTORIC CITY: PERCEPTIONS AND MODES OF LOCALISATION IN FLORENCE, ITALY. A METHOD OF ANALYSIS AND INTERPRETATION
}

\author{
Sabrina JEAN
}

CRESO - UMR ESO. Geography Departament (Universidad of Caen)

Has one of you - geographer, sociologist, economist - already had between your hands a work which deals with Florence and its inhabitants? If not, you surely have already had the occasion to read works dealing with the cultural treasures and importance of the city throughout history. However, today, there is little interest in this city, paradoxically one of the most famous in the world.

The search that is undertaking on Florence ${ }^{1}$ aims to study the processes of socio-functional transformations in intra-urban space. One point of this study focuses on the image of the "historic city". I suggest that the historical cities are subjected to particular dynamics within European cities. The method elaborated to study those dynamics centres on the urban form, the different actors' perceptions and their city modes of appropriation. This method is reproducible for the study of other "historic cities".

The particular objective of this paper is to show that the historical centre is a pole in the city. This part of the city is thought of as the "historic city" itself. Thus, the historical centre captures the interest of both the international community and the Florentine urban planners to define it as the historic city. This way, it also captures the tourist and private investment interests. That makes emerge particular tensions - from structural one to social one - within the whole urban territory. There are two Florences : the guides' one (the tourist and users' one) and the daily Florence (the inhabitants' one).

It will be shown the images of the "historic city" at the international level and in the town planners' experiences. Then, it will be shown how those images influence the experiences of the city, the tourist's one on the one hand, and the inhabitants' one on the other. It will be connected with their modes of

\footnotetext{
${ }^{1}$ JEAN, S. (2001), «Transformations socio-fonctionnelles d'une " ville historique" : l'exemple de Florence», PhD project, not published.
} 
localisation.

\section{THE LIMITS OF THE CITY.}

At the international scale, there are a lot of writings about Florence but they are strictly limited to historical studies of the space enclosed inside the latest walls. This area would represent the historic city. It's an international tradition to limit the whole city of Florence to this part of the urban territory and to its famous monuments.

There are few writings about the other Florence, the one of the inhabitants. I have to mention Vasco Pratolini's Balcony in Florence ${ }^{2}$ which describes the popular life in Florence under the fascist period. Recently, Antonio Tabucchi ${ }^{3}$ violently spoke of the Renaissance image of the city and laid stress upon how residents are forgotten. He particularly described the Zingary's life in the camps outside the city centre.

Few are those who speak about contemporary Florence apart from geographers, sociologists and architects at the University of Florence. It particularly has to be mentionned the work of an architects' group ${ }^{4}$ studying the contested spaces within the city.

The little information and studies of the city, outside the city centre, raises the question of the interest in studying the city today. Why speak about the other Florence, that of the inhabitants? Why speak about Florence like a modern European average city? Nobody may find it beneficial to propose the modern Florence! Nobody may find it beneficial to speak about the difficulties of the city, with the archaism of certain actions, with the absence of stimulations of certain urban zones! People may not find it beneficial to speak about the Roms camps! Why aren't the images of Zingari, of the African blacks sauntering in the city, beggars or street hawkers revealed throughout the world like that of Duomo or the David? Why does nobody want to speak about the inhabitants, about their way of life, which may be so particular, we can imagine, for someone living in such a city?

\footnotetext{
2 Pratolini, V. (1992), Un balcon à Florence, Actes Sud, Paris

${ }^{3}$ TABUCCHI, A. (1999), Gli Zingari e il Rinascimento. Vivere da Rom a Firenze, Librerie Feltrinelli, Milano.

${ }^{4}$ PABA, G. ed al. (to be published), Florence Insurgent City.
} 


\subsection{A concept.}

What is in the today's reality the 'historic city'? Is the whole urban entity the 'historic city'? Most of the time, with regard to the survey that has been carried out, in the writings and in the intellectual thought, the 'historic centre' only corresponds to the city centre. Rather than a reality, the 'historic centre' seems to be a concept or an image pre-produced or pre-made of the city. This 'historic city' corresponds to the cultural, architectural and aesthetic inherited form of the city centre. It will be significant to speak about the inherited city in this case. On the current map of the city this inherited city corresponds to the city centre, district 1 . There are elements, structures of elements, plan $^{5}$ which recalled the long and prestigious construction of the city.

The historic city is linked to the heritage and inheritance concepts. In the history, the importance of such a city is well known and that's why it is on the UNESCO historical cities list. What could also be considered as historical is the fact that the men who live in the city, the urban communities who produced it, have been able to prolong it until today. Even if the historical core is clearly very important for international cultural history, one can ask what is the city outside the centre, if it's not the historic prolongation of the city made by the Florentine community? Florence town planners give a very particular response.

\subsection{A definition built on oppositions.}

The prestigious value of the city centre as well as the concept of 'historic city' is used by the Florentine towns planners. They clearly opposed in the structure plan of 1992 different parts of the city, such as: the historic city, the consolidated city, and the non-city within the intra-urban space.

The historic city is, in this vision, a part of the city as shown on this map. The city centre polarises the attentions of the urban planners and of their private partners, because of the assets it can boast of, in terms of attraction and establishment of prestigious activities, of tertiary and higher tertiary functions. The preferential localisation of the activities of services and prestige in the central zone of the city still comes to reinforce the definition of "historical city"

\footnotetext{
${ }^{5}$ CANiggia, G., Malfroy, S. (1986), «L'approche morphologique de la ville et du territoire», ETHZ, Zürich ; KRISTJANSDOTTIR, S. (2001), The integration of architectural and geographical concepts in urban morphology: preliminary thoughts, Urban morphology research group, University of Birmingham
} 
in charge of cultural values (and pecuniary) which thus supports the privileged localisation of this certain type of activity. The historical city is then characterised by the secure income which it represents. It's opposed to the "remainder of the city", in the way that it does not offer the same capacities of attraction.

The consolidated city is the peri-central zone. It is subjected to processes of attraction supported by the proximity of the historical center. This space is characterised by the emergence of urban vacuums since the eighties, which constitute as shown by Indovina ${ }^{6}$ "full of revenue".

There's a play which has been set in both these defined kinds of space. It's a play between public and private partners within the framework of the policy of the Great Projects. There are plans of recovery and rehabilitation set up at great advertising reinforcement. There are planned developments by famous architects. All of this contributes to the functional transformation of central and peri-central spaces. For example, the enquiry and interviews of social actors in district 1 that I made, show a tertiarisation of the central zone. The buildings located in the central area are more and more reinvested in functional activities, tertiary and prestigious activities. The amount of housing in the centre is thus falling and their prices are rising. There's thus tertiarisation of the centre to the profit of the investors and users of the city, whereas the inhabitants claim in the peripheral districts in which the number of residents increased since the 1980's services for districts "to live in".

The rest of the city, as shown on this map, is called in the structure plan of 1992 the non city. This non city is the one with structural deficiencies and lack of services and finally the one of little cultural and investment value. This is, however, the very dynamic part of the city in terms of inhabitant dynamics. The enquiry I made in Florence in 2000-2001 found a lot of persons involved in the development of those "non parts" of the city. The Piagge and Isolotto are, for example, some very dynamic neighbourhoods. People there are trying to involve the population in the development of the district even with little financial means. A lot of problems have been resolved in Florence by the inhabitants themselves which has to be know, even as examples to serve other historic cities of residents.

\footnotetext{
${ }^{6}$ Indovina, F. (1993), La città occasionale. Firenze, Napoli, Torino, Venezia, Franco Angeli, Milano.
} 


\section{THE INTERRELATION BETWEEN THE HISTORIC CITY AND THE TOURIST CITY.}

The tourist orientation, by the different guides or writings as well as by the municipality, individualises the historic city as part, an entity, within the city. Isn't the 'historic city of Florence' a product, thought of at the international scale, which will only have sense for those who consume it, tourists and users?

Urban management, trajectories, historic tourist publications made to define what is historic in the city. The form of intra-urban space, and especially the absence of tourist beacons beyond the viali, hardly encourage one to venture beyond the front. From a structural point of view these viali constitutes a strong barrier, reinforced in the imaginary by the absence of tourist development. The communal responsibility is, in my opinion, strong on the one hand in the lack of interest carried to peri-central spaces and on the other hand in their management because of the weak character on homogenisation of intra-urban space in the communal urbanistic practices, the way to conceptualise the city as made of different and hermetic parts.

\subsection{The consumed city}

If one could spatially project the areas and elements in the writings at the international scale, it would be clear that the fame of Florence is only one of a part of the urban territory. The other Florence is not known at all!

The analysis of the tourist trajectories within the city clearly show a consumed city. It is the tourist-historic city. That is the city known as a touristhistoric product, what one came to find with regard to one's cultural needs and tourist expectations.

The historic city is once again a city within the city, a city 'had' by the tourists and users, a city of which the use is "intended" for certain kinds of persons, but which is not the Florentines' city anymore.

More and more emerged in the city are 'contested spaces', which researchers at the university of architecture are trying to make emerge. The question of the public spaces within the city is arising as a very important question. It's in part the question of whose city. Recently troubles took place between young Florentines and the police in a park in the central area. The municipality increasingly limits access to the parks and the places. The regrouping and manifestations of the young people of Florence are increasingly restricted. It is 
still the question of the image of the city, at the international level and tourists' point of view, which is at question.

\subsection{Times of the city.}

The historic city is individualised as a particular space within the city, enclosed in a very small zone with regard to its tourist use. Because of the particular interest which is attached to this area, tertiary and particularly tourist function, it's a zone submitted to very particular rhythms with regard to the other parts of the city. The recognition of the historic city as the place to see, even as the place to be and the place to go, to benefit particular kinds of services, and make it a very chaotic zone.

More and more groups of people cross each other there without exchanges. My experience of the Florentine way of life made me understand why the inhabitants ran away from the city centre. It's often necessary to queue beside Japanese, Americans or others groups to cross the area. There's a lot of traffic and people in the zone. Places are no more places to meet but have become places to sell. One of the problems linked to tourism within historic cities is the degradation of social interaction. Groups are there for a short time, they have to see everything they want to, and to buy all of the 'made in Tuscany' products they heard about. And as we will now see, it's also a problem of the interaction of the Florentines themselves.

\section{TO REBUILD THE IMAGE OF THE CITY.}

\subsection{To transcribe the daily reality of intra-urban space.}

To understand what is the reality of the intra-urban space today, and what is the reality of the "historic city" in daily reality, it has been pointed out the necessity to refer to the inhabitants' point of view and mode of localisation.

In the practices of the residents, the historic city and the historic centre, represent a space which is not theirs any more, but sold on the international tourist market.

From a research about the social structure of Florence in 1981 and $1991^{7}$, and

\footnotetext{
${ }^{7}$ JEAN, S. (2000), La structure socio-fonctionnelle de l'espace intra-urbain florentin, Master degree, not published.
} 
the particular study of segregation and modes of localisation in the intra-urban space, it emerges that:

- A process of reappropriation of central space by the higher social classes, has been stimulated by the increase of the tertiary, higher tertiary and prestigious functions on the urban scale, and the privileged establishment that the zone represents. In term of activities, this zone is also gravitational, from the international and tourist point of view, and meets the needs for this category of the population (cultural activities, places of output).

- The excessive rents and the scarcity of the residences in the centre, the difficulties of circulation and the characteristic of the mode of life inherent to the centre (ceaseless flows, difficulty of circulation and parking problems, (related to tourism) lead to the ousting of young couples with children (the centre constitutes a zone where few young children are found, it is also understood that people do not want to walk their children in a zone of perpetual chaos and pollution such as that of the central zone).

It is also the ousting of the old people. Owners prefer to rent out their apartments at high prices and for short periods to the Japanese or Americans of passage. The tensions in term of housing in Florence, are stimulated by a keen demand for and prestigious localizations. For the inhabitants, it is generally preferable to settle on the periphery or away from the city. The number of residents is thus in constant fall on an intra-urban scale. One notes in particular an increasing concentration of the populations belonging to the lower social categories in the western parts of the city.

The 'historical city' empties out its inhabitants. The urban way of life is more and more the one of a consumed city rather than the one of a city to experience. The mode of localisation of the inhabitants contributes to reducing the social interaction more and more. What remains of the Florentine Florence, that of the inhabitants, whose anger has not ceased to increase?

\subsection{Historic city or city to live in?}

At the beginning of this lecture, it has been asked what is the historic city today. It can be briefly said that it is:

- An image. It's the cultural and aesthetic portion of the actual urban 
territory. It's the inherited city, but the one often thought of as the whole Florence.

- A town planning concept. It's a very particular portion of the city, with more and more peculiar value, submitted to an increasing expansion of the service sector.

- But as the Product Of The Urban Community, in the real sense of way of life and social interaction, the historic city is declining. The study ${ }^{8}$ of the segregation processes and of the inhabitants' mode of localisation shows a city more and more divided in parts. Each of them is strongly charged with particular values and invested with transformations linked to those values.

The historic city should be defined as the organic urban community development of it. Instead it is a 'tutto turismo' city. That is a city thought of for the tourists and private interests, as a portion in the intra-urban space, in connection with the value it represents.

\section{CONCLUSION: DANGERS OF TOURISM ON THE CITY.}

This communication aimed to show the importance of perceptions and interpretations of a portion of urban territory as historic in the functional and social transformations of the city. It is particularly the tourists' and planners' perception of it as a source of profit. The dangers of tourism in the city are not only those of monument and masterpiece degradation. It's also the degradation of social interrelationships. The historic city, as the community organic production, is no more a city to live in but a city to consume.

On the one hand, it's now necessary to study the historic city as the whole urban territory strongly connected to the historical centre. This kind of study should be linked (on the other hand) to urban planning. It is to recompose the city, to connect its different parts in an homogeneous way. It could be done by integrating the inhabitants' participation to the urban program, as asked for more and more by social actors of the city today in every neighbourhood.

\footnotetext{
${ }^{8}$ JEAN, S. (2000), ibid.
} 